\title{
The Association of Glutathione S-Transferase P1 Polymorphism to Imatinib Mesylate Resistance in Chronic Myelogenous Leukemia Patients According to Haematology Response at General Hospital Haji Adam Malik and Branch Hospital in Kota Medan
}

\author{
Ainun Basyiroh Lubis ${ }^{1}$, Dairion Gatot ${ }^{2}$, Savita Handayani ${ }^{2}$, Henny Syahrini ${ }^{2}$ \\ ${ }^{1}$ Department of Internal Medicine, Faculty of Medicine, Universitas Sumatera Utara, Medan, Indonesia \\ ${ }^{2}$ Division of Hematology and Medical Oncology, Department of Internal Medicine, Faculty of Medicine, \\ Universitas Sumatera Utara, Medan, Indonesia
}

Corresponding Author: Ainun Basyiroh Lubis

\begin{abstract}
Objective: Variations in the genes coding for drug metabolism enzymes may explain the variability response to treatment. Previous studies reported that GSTP1 polymorphism was associated with the incidence of Imatinib Mesylate resistance as first-line therapy in CML patients. This study aims to determine the association between GSTP1 polymorphism and Imatinib Mesylate resistance in CML patients according to haematology response.

Methods: Total of 46 people (consisting of 23 CML patients with Imatinib Mesilat resistance and $23 \mathrm{CML}$ patients without Imatinib Mesilat resistance) at General Hospital H. Adam Malik and branch hospital in Medan City, Indonesia was analyzed in this study. Blood samples were taken for examination of GSTP1 polymorphism through Polymerase Chain Reaction (PCR). Resistance status was taken from medical records based on ELN criteria. Data were analyzed using Fisher's Exact test; $p$ value $<0,05$ was applied to each statistical test as significant. Result: The distribution of research subjects characteristic was divided into imatinib resistance and non-imatinib resistance groups. In both cases, the highest frequency was found in male $(65,2 \%$ and $69,6 \%)$ in $35-44$ years old group $(34,8 \%$ and $39,1 \%)$. In the imatinib resistance group, the highest frequency was found in Javanese $(39,1 \%)$ and GSTP1 polymorphism Ile/Ile $(65,2 \%)$. In the nonimatinib-resistant group, the highest frequency
\end{abstract}

was found in Batak tribe $(43,5 \%)$ and GSTP1 polymorphism Ile/Val (52,2\%). This study found 11 cases of leukocytosis and 7 cases of thrombocytosis in the imatinib resistance group. According to statistical measurement, $\mathrm{p}$ value was $0,142(\mathrm{p}>0,05)$.

Conclusion: The association of GSTP1 polymorphism to imatinib mesylate resistance in chronic myelogenous leukemia patients according to haematology response was not significant.

Keywords: Chronic Myeloid Leukemia, GSTP1 Polymorphism, Imatinib Mesylate Resistance

\section{INTRODUCTION}

Chronic myelogenous leukemia (CML) is a myeloproliferative disorder of primitive haemopoietic stem cell which characterized by overproduction of myeloid cells. CML is identified by Philadelphia chromosome; ABL (Abelson) with BCR (break cluster region) gene at long arms of chromosome 22(22q11). ${ }^{1}$

CML is more common in older population (more than 50 years old). The incidence rate of this case is about $1-1,5$ per 100.000 population each year. ${ }^{2}$ The incidence of leukemia in Indonesia is estimated at 5,3 out of 100.000 population and the mortality rate is about 4,4 out of 100.000 population. $^{3}$ 
Ainun Basyiroh Lubis et.al. The association of glutathione s-transferase pl polymorphism to imatinib mesylate resistance in chronic myelogenous leukemia patients according to haematology response at General Hospital Haji Adam Malik and Branch Hospital in Kota Medan.

Xenobiotic metabolizing enzyme plays an important role in the metabolism process of chemotherapy agents. Polymorphisms in genes encoding drug metabolizing enzymes were vary in enzymatic activity and pharmacokinetic variability. Therefore, this condition potentially modifying response and resistance to treatment or drug toxicity. ${ }^{4}$

Glutathione S-transferase P1

(GSTP1) is a $\mathrm{Pi}$ gene, located on chromosome 11q13. ${ }^{4}$ GSTP1 polymorphism (Ile105Val) produced three types of GSTP1 genotype, namely: homozygous type Ile/Ile, heterozygous type Ile/Val, and homozygous variant $\mathrm{Val} / \mathrm{Val} .^{5}$

Imatinib mesylate is a phenylaminopirimidine molecule that plays a role as BCR-ABL tyrosine kinase enzyme inhibitors. This enzyme is expressed on the leukemic cells of most patients with CML. ${ }^{6}$ Based on previous studies, imatinib mesylate is a monoclonal antibody (STI 571) to inhibit the tyrosine kinase activity of the BCR-ABL gene fusion, but treatment resistance arises. Resistance mechanisms are generally divided into two: dependent and independent BCR-ABL. ${ }^{7}$

Due to the increasing of point mutations, new inhibitors have been developed with a rational drug design approach. The second-generation of inhibitor drugs were found to be able to resolve cases of resistance. ${ }^{7}$

To assess the response to therapy, monitoring must be carried out by assessing the hematological response, which consists of complete blood count, white blood cell differentiation and spleen measurement. The ideal response to treatment using TKI was detected during long-term treatment monitoring. The goal of TKI treatment is to achieve an ideal response haematologically, cytogenically, and molecularly. ${ }^{8}$

The association of GSTP1 polymorphism to imatinib mesylate resistance is still being debated. One study in Malaysia showed that patient with GSTP1 Ile105Val genotype are at risk of developing imatinib mesylate resistance.
The heterozygote and homozygote variant had a significant value; $49,3 \%$ and $11 \%$ in imatinib resistance group, while in nonresistance group, it was $37,1 \%$ and $4,6 \%$; $\mathrm{p}=0,013 .{ }^{9}$ Similarly, in India it was found that the GSTP1 Ile105Val polymorphism had a significant relationship with the development of CML ( $\mathrm{p}=0.0084)$; and Iran with $\mathrm{p}=0.04$. $^{10,11}$

However, there was controversy in Romania where patients with the GSTP1 Ile105Val genotype had no associated risk of developing resistance to imatinib mesylate in CML patients, which was $22.9 \%$ in patients with CML and $17.4 \%$ in controls $(p=0.07)$. Similarly, the study in Sudan found that no association between the GSTP1 polymorphism and the risk of CML $(\mathrm{p}=0.417)$; and Turkey with $\mathrm{p}=0.199 .^{12,13}$

\section{METHODS}

This study is an analytical study with case-control retrospective design which aims to determine the association between GSTP1 polymorphism and Imatinib Mesylate resistance in CML patients according to haematology response.

The target populations in this study were CML patients with or without imatinib mesylate resistance, while the accessible populations were CML patients with or without imatinib mesylate resistance who are outpatients at Haemato-Oncology Division, General Hospital Haji Adam Malik and branch hospital in Medan. The sampling technique used in this study was consecutive sampling, in which all subjects were involved in the study as long as they met the inclusion and exclusion criteria.

\section{Inclusion Criteria:}

a. CML patients who seek treatment at General Hospital Haji Adam Malik and branch hospital in Medan.

b. CML patients taking imatinib as the first line therapy.

\section{Exclusion Criteria:}

a. Pregnant 
Ainun Basyiroh Lubis et.al. The association of glutathione s-transferase pl polymorphism to imatinib mesylate resistance in chronic myelogenous leukemia patients according to haematology response at General Hospital Haji Adam Malik and Branch Hospital in Kota Medan.

b. CML patients who are not willing to participate in this study.

The 46 samples (consisting of 23 CML patients with Imatinib Mesilat resistance and $23 \mathrm{CML}$ patients without Imatinib Mesilat resistance) in this study was determined by total sampling method.

\section{Procedures}

All of CML patients with or without imatinib mesylate resistance who seek treatment at Haemato-Oncology Division, General Hospital Haji Adam Malik and branch hospital in Medan was selected according to inclusion and exclusion criteria. Samples in this study were asked to assign a written consent regarding subject willingness to participate in this study (informed consent).

Data of subjects (age, sex, religion, tribe, marital status, haematology or BCRABL response) were collected from medical records to determine the resistance status to imatinib mesylate. Subjects were carried out with blood sampling for PCR to detect GTSP1 polymorphism.

\section{Measurements \\ Chronic Myeloid Leukemia (CML) \\ Resistance Criteria}

The criteria for resistance to treatment failure using imatinib were assessed relative to the duration of therapy with an assessment of hematological response (Leucocyte >10.000; Platelet $>450.000)$ or BCR-ABL $(>10 \%)$. The criteria used are in accordance with European Leukemia Net (ELN) criteria.

\section{GSTP1 Polymorphism}

GSTP1 polymorphism detected by PCR was divided into 3 groups (Ile/Ile, Ile/Val, and $\mathrm{Val} / \mathrm{Val}$ ).

\section{Statistical Analysis}

Univariate and bivariate analyzes were performed on the data in this study. Univariate analysis was performed to obtain the distribution of sample characteristics.

Bivariate analysis was performed to determine the relationship between the independent and dependent variables. This study used Fisher test as the statistical assessment; because the data was categorical and Shapiro Wilk normality test showed $p=0,0001$. Statistical analysis was performed using the SPSS 20 (Statistical Package for Social Sciences) computer program where the $\mathrm{p}$ value $<0.05$ was significant.

\section{Ethical Clearance}

Ethical clearance is a written statement provided by the research ethics commission for research involving living things as well as humans, animals and plants, where it is stated that a research proposal is feasible after meeting certain requirements.

This research will be conducted after obtaining permission to carry out research from the research supervisor, approval from the USU Medical Faculty Research Ethics Commission, and after obtaining permission from the head of the hemodialysis unit at RSUP HAM. As ethical considerations, researchers believe that respondents' rights is secured by paying attention to aspects such as Self Determination, Informed Consent, Privacy, Anonymity and Confidentiality, and Protection from Discomfort

\section{RESULTS \\ Sample characteristics}

Table 1 shows that based on age, imatinib resistance and non-resistance were most commonly found at the age of 35-44 years, respectively 8 patients $(34.8 \%)$ and 9 patients $(39.1 \%)$. As for gender, cases of imatinib resistance and non-resistance were most commonly found in male, respectively 15 patients $(65.2 \%)$ and 16 patients $(69.6 \%)$. There was no difference in frequency based on religion between patients with resistance and non-imatinib resistance. Based on marital status, the highest number of imatinib resistance and non-imatinib resistance was found in married patients, respectively 22 patients $(95.7 \%)$ and 20 patients $(87.0 \%)$. Based on 
Ainun Basyiroh Lubis et.al. The association of glutathione s-transferase p1 polymorphism to imatinib mesylate resistance in chronic myelogenous leukemia patients according to haematology response at General Hospital Haji Adam Malik and Branch Hospital in Kota Medan.

ethnic, it was found that the highest imatinib resistance rate occurred in Javanese $(39.1 \%)$, while the highest non-imatinib resistance rate occurred in Bataknese $(43.5 \%)$.

\begin{tabular}{|c|c|c|}
\hline Variable & $\begin{array}{l}\text { Imatinib } \\
\text { Resistance }(n=23)\end{array}$ & $\begin{array}{l}\text { Non Imatinib } \\
\text { Resistance }(\mathrm{n}=\mathbf{2 3})\end{array}$ \\
\hline $\begin{array}{l}\text { Age Group } \\
25-34 \\
35-44 \\
45-54 \\
55-64 \\
65-74 \\
\end{array}$ & $\begin{array}{l}4(17,4 \%) \\
8(34,8 \%) \\
7(30,4 \%) \\
2(8,7 \%) \\
2(8,7 \%)\end{array}$ & $\begin{array}{l}7(30,4 \%) \\
9(39,1 \%) \\
5(21,7 \%) \\
2(8,7 \%) \\
0(0,0 \%)\end{array}$ \\
\hline $\begin{array}{l}\text { Gender } \\
\text { Male } \\
\text { Female } \\
\end{array}$ & $\begin{array}{l}15(65,2 \%) \\
8(34,8 \%)\end{array}$ & $\begin{array}{l}16(69,6 \%) \\
7(30,4 \%)\end{array}$ \\
\hline $\begin{array}{l}\text { Religion } \\
\text { Muslim } \\
\text { Christian } \\
\end{array}$ & $\begin{array}{l}16(69,6 \%) \\
7(30,4 \%)\end{array}$ & $\begin{array}{l}16(69,6 \%) \\
7(30,4 \%)\end{array}$ \\
\hline $\begin{array}{l}\text { Ethnic } \\
\text { Batak } \\
\text { Karo } \\
\text { Nias } \\
\text { Mandailing } \\
\text { Jawa } \\
\text { Melayu } \\
\end{array}$ & $\begin{array}{l}6(26,1 \%) \\
1(4,3 \%) \\
1(4,3 \%) \\
3(13,0 \%) \\
9(39,1 \%) \\
3(13,0 \%) \\
\end{array}$ & $\begin{array}{l}10(43,5 \%) \\
2(8,7 \%) \\
0(0,0 \%) \\
1(4,3 \%) \\
6(26,1 \%) \\
4(17,4 \%) \\
\end{array}$ \\
\hline $\begin{array}{l}\text { Marital Status } \\
\text { Married } \\
\text { Unmarried }\end{array}$ & $\begin{array}{l}22(95,7 \%) \\
1(4,3 \%)\end{array}$ & $\begin{array}{l}20(87,0 \%) \\
(13,0 \%)\end{array}$ \\
\hline
\end{tabular}

\section{GSTP1 Polymorphism and Haematology} Response Distribution

According to PCR-RFLP, the PCR results in this study were 433 basepair (bp). Wild-type (AA/ Ile105Ile) was found at 433 bp, heterozygous variant (AG/lle105Val) was found at $433 \mathrm{bp}$ and $327 \mathrm{bp}$, while homozygous variant (GG/Val105Val) was found at 327 and $106 \mathrm{bp}$. GSTP1 polymorphism pattern were served in figure 1.

Table 2 shows that the GSTP1 Ile/Ile genotype was found to be the most common in imatinib resistance cases $(65.2 \%)$ and Ile/Val genotype in non-resistance cases $(52.2 \%)$.

The hematological response of the resistance group was: (1) mean value of $\mathrm{Hb}$ : $10.74 \pm$ SD 1.99; (2) Leukocytes: $34724 \pm$ SD 57568; (3) Platelets: $497869 \pm$ SD 476381. Leukocytosis and thrombocytosis were found in imatinib resistance group, respectively 11 patients and 7 patients. Meanwhile, the haematological response of non-resistance group was: (1) mean value of Hb: $11.68 \pm$ SD 1.65; (2) Leukocytes: 7393 \pm SD 1847; (3) Platelets: $244565 \pm$ SD 80385 .

Table 2. GSTP1 Polymorphism and Haematology Response

\begin{tabular}{|c|c|c|}
\hline Variable & Imatinib Resistance $(n=23)$ & Non Imatinib Resistance $(n=23)$ \\
\hline $\begin{array}{l}\text { GSTP1 Polymorphism } \\
\text { Ile/Ile } \\
\text { Ile/Val } \\
\text { Val/Val }\end{array}$ & $\begin{array}{l}15(65,2 \%) \\
7(30,4 \%) \\
1(4,3 \%)\end{array}$ & $\begin{array}{l}8(34,8 \%) \\
12(52,2 \%) \\
3(13,0 \%)\end{array}$ \\
\hline $\begin{array}{l}\text { Haematology Response } \\
\text { Hemoglobin }(\mathrm{Hb}) \\
\text { Leukocyte (Leu) } \\
\text { Platelet (Plt) }\end{array}$ & $\begin{array}{l}\text { Mean } 10,74 \pm \text { SD } 1,99 \\
\text { Mean } 34724 \pm \text { SD } 57568 \\
\text { Mean } 497869 \pm \text { SD } 476381\end{array}$ & $\begin{array}{l}\text { Mean } 11,68 \pm \text { SD } 1,65 \\
\text { Mean } 7393 \pm \text { SD } 1847 \\
\text { Mean } 244565 \pm \text { SD } 80385\end{array}$ \\
\hline $\begin{array}{l}\text { Interpretation of Haematology Response } \\
\text { Leucocytosis } \\
\text { Non Leucocytosis } \\
\text { Thrombocytosis } \\
\text { Non Thrombocytosis }\end{array}$ & $\begin{array}{l}11 \\
12 \\
7 \\
16\end{array}$ & $\begin{array}{l}0 \\
23 \\
0 \\
23\end{array}$ \\
\hline
\end{tabular}

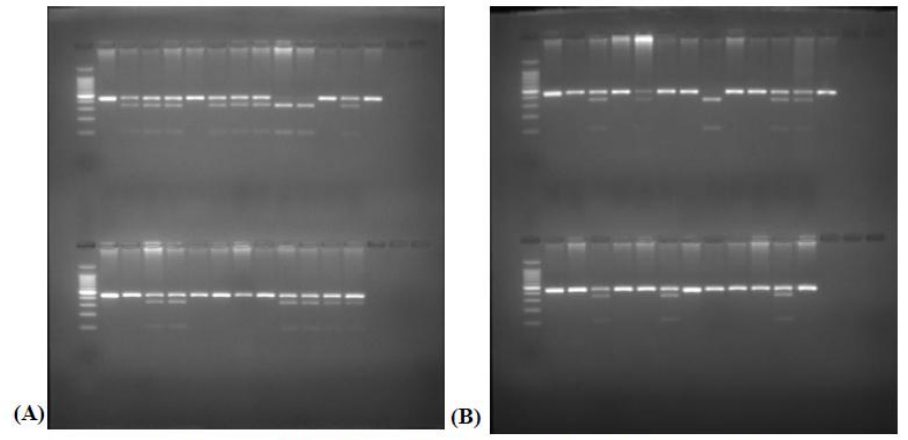

Figure 1. GSTP1 polimorphism pattern (a) Control (non-resistance);

(b) Imatinib mesylate resistance 
Ainun Basyiroh Lubis et.al. The association of glutathione s-transferase pl polymorphism to imatinib mesylate resistance in chronic myelogenous leukemia patients according to haematology response at General Hospital Haji Adam Malik and Branch Hospital in Kota Medan.

1.1 Association of GSTP1 Polymorphism to Imatinib Mesylate Resistance

Data of this study were not normally distributed (with Shapiro Wilk, $\mathrm{p}=0,001$ ), therefore the statistical test carried out with fisher exact test.

Table 3 shows that in this study the GSTP1 Ile/Ile genotype (the supposed homozygous type) was 15 in imatinib resistance group and 8 in non-resistance group. Ile/Val polymorphism was 7 in resistance group and 12 in controls. In addition, the homozygous $\mathrm{Val} / \mathrm{Val}$ polymorphism was found in 1 patient of resistance group and 3 patients of nonresistance group. The association between variables in this study is not statistically significant $(\mathrm{p}=0,142)$.

Table 3. Association of GSTP1 Polymorphism to Imatinib Mesylate Resistance

\begin{tabular}{|l|l|l|l|}
\hline \multirow{2}{*}{$\begin{array}{l}\text { GSTP1 } \\
\text { Polymorphism }\end{array}$} & Status & \multirow{2}{*}{$\mathbf{p}=\mathbf{0 , 1 4 2} *$} \\
\cline { 2 - 3 } & Resistance & $\begin{array}{l}\text { Non } \\
\text { Resistance }\end{array}$ & \\
\hline Ile/Ile & 15 & 8 & \\
\hline Ile/Val & 7 & 12 & \\
\hline Val/Val & 1 & 3 & \\
\hline
\end{tabular}

\section{DISCUSSION}

Variations in the genes coding for drug metabolism enzymes may explain the variability response to treatment. This can be used as a determinant of the assessment of the response therapy. Polymorphism can lead to a lack of enzyme activity and a reduced detoxification role in GST. ${ }^{4}$

In this study, the most GSTP polymorphisms were Ile/lle, followed by $\mathrm{Ile} / \mathrm{Val}$, and $\mathrm{Val} / \mathrm{Val}$ with the least number found in resistance cases. A study in Romania by Banescu et al. (2014) found that the spread of the GSTP 1 polymorphism in CML patients was Ile/Ile (61.9\%), Ile/Val (30.4\%), and $\mathrm{Val} / \mathrm{Val}$ (7.7\%). In concordance with the study in Sudan by Idris et al., Ile/Ile was found as much as $65 \%$, Ile/Val $31.5 \%$, and $\mathrm{Val} / \mathrm{Val}$ $3.5 \%$. A study in Turkey by Karkucak et al showed the percentage of Ile/Ile was $64.2 \%$, $\mathrm{Ile} / \mathrm{Val} 29.6 \%$, and $\mathrm{Val} / \mathrm{Val} 7.04 \% .^{11,12,13}$

In addition to the GSTP1 polymorphism, this study also assessed the description of the hematological response of the study subjects and found the average leukocyte count in resistance group was $34724 \pm$ SD 57568, with an average hemoglobin level of $10.74 \pm$ SD 1.99, and an average platelet count. $497869 \pm$ SD 476381. Karkucak et al showed the average level of leukocyte was 129,590 \pm SD 130,947. Meanwhile, Elhoseiny et al showed an average value of leukocyte count was 88,800 $\pm 83,600$; hemoglobin: $9.5 \pm 2$; and platelet count: $371,600 \pm 286,000$. The results of each study were almost similar, where the hematological response of leukocytes must reach $<10$ x $10^{9} / \mathrm{L}$. However, due to imatinib mesylate resistance, the target was not achieved. There are quite varied data regarding hematological parameters. ${ }^{13,14,15}$

Although there have been a number of studies conducted in different populations to evaluate the role of GST polymorphisms in the incidence of CML and response to therapy, the significance of this association remains controversial. This inconsistent nature may be related to geographical and ethnic differences in study samples. However, involvement of certain demographics in incidence of imatinib mesylate resistance is still a matter of debate. The distributions of samples in this study found that ethnic group with the highest risk for imatinib resistance were Javanese $(39.1 \%$ ), followed by Bataknese $(26.1 \%)$ and Mandailing (13.0\%). In Indonesia, there is still no study similar to the research conducted by researchers, so it is very limited to show other data. ${ }^{10}$

Elhoseiny et al. (2014) showed that there was an association between the GSTP1 polymorphism and poorer haematological response. Patients who did not achieve complete remission had polymorphisms (50\% homozygous and 50\% heterozygous) with $\mathrm{p}$ value $=0.05$ based on haematological response and $\mathrm{p}=<0.001$ based on cytologic response. Makhtar's (2017) in Malaysia found that the frequency of GSTP1 heterozygous variant polymorphisms in the resistant group was significantly higher compared to the group 
Ainun Basyiroh Lubis et.al. The association of glutathione s-transferase p1 polymorphism to imatinib mesylate resistance in chronic myelogenous leukemia patients according to haematology response at General Hospital Haji Adam Malik and Branch Hospital in Kota Medan.

that had a good response to therapy ( $\mathrm{p}=$ $0.041)$. An assessment of the association of the GSTP1 Ile105Val polymorphism with response to imatinib mesylate was conducted and it was found that heterozygous and homozygous variants were associated with resistance to imatinib mesylate $(\mathrm{OR}=1.951 ; 95 \% \mathrm{CI}=1.186-$ $3.209 ; \mathrm{P}=0.009-\mathrm{OR}=3.450 ; 95 \% \mathrm{CI}=$ $1.305-9.606 ; \mathrm{P}=0.013$. ${ }^{4,14}$

In this study, the association of GSTP1 polymorphism to imatinib mesylate resistance in CML patients was found to be insignificant $(\mathrm{p}=0.142)$. This is in line with research by Sailaja et al. (2010), where there was no association between hematological response and GSTP1 polymorphism. Meanwhile, the frequency of Ile/Val and $\mathrm{Val} / \mathrm{Val}$ genotypes was found to be increased in the poor $(41.6 \%)$ and minor $(53.57 \%)$ cytogenetic response groups compared to the major $(38.51 \%)$ response groups. This was also stated by Karkucak et al where there was no association between CML resistance and GSTP1 polymorphism $(\mathrm{P}=0.822 ; \mathrm{P}=0.138){ }^{9,13}$

Although there were no significant results on the association between imatinib mesylate resistance and GSTP polymorphism in this study, the number of cases used was still smaller than the population of other polymorphism studies. Due to these limitations, further studies require a larger sample with a wider geographic and ethnic spectrum. Apart from the sample size, this study did not have sufficient information regarding other environmental factors that influence treatment response.

Several studies with insignificant results were also carried out using a smaller sample size and using a wider confidence interval. So, this research needs to be confirmed by further research using a larger population with a larger number of controls. Other variables that influence the incidence of imatinib mesylate resistance in CML patients are also recommended to be included in further research.

\section{CONCLUSION}

Based on the results of the research described above, the conclusions that can be drawn are: (1) imatinib resistance and nonimatinib resistance are most commonly found at the age of 35-44 years, male gender, Muslim religion, and married patients. Javanese are the most common in the resistance group and Bataknese in the non-resistance group; (2) The most common GSTP1 polymorphism pattern found in the imatinib resistance group was Ile/Ile. Meanwhile, Ile/Val was the most common pattern in the non-imatinib resistance group. Leukocytosis (11 cases) and thrombocytosis (7 cases) were found in imatinib resistance group; (3) the association of GSTP1 polymorphism to imatinib mesylate resistance in chronic myelogenous leukemia patients according to haematology response was not significant.

\section{Acknowledgement: None}

\section{Conflict of Interest: None}

\section{Source of Funding: None}

Ethical Approval: Approved

\section{REFERENCES}

1. Alwi, Idrus. Leukemia dalam: Penatalaksanaan di Bidang Ilmu Penyakit Dalam Panduan Praktik Klinis Perhimpunan Dokter Spesialis Penyakit Dalam Indonesia.2015;:, 511.

2. Rathore Ritesh. Chronic Myelogenous Leukemia in: Ferri's Clinical Advisor. Ed. 1st. Elsevier Saunders: Philadelphia.2020; 345-6

3. Globocan. The Global Cancer Observatory: Indonesia. 2018;1

4. Makhtar, S.M, Husin, A, Baba, A.A, Ankathil, R. Association of GSTM1, GSTT1 and GSTP1 gene (I105V) polymorphism with clinical response to imatinib mesilat treatment among Malaysian chronic myeloid leukaemia patiens acute leukaemia. Journal of genetics. 2017;.633639.

5. Dunna, N.R., Vuree, S., Kagita, S., Surekha, D., Digumarti, R., Rajappa, S. and Satti, V.. 
Ainun Basyiroh Lubis et.al. The association of glutathione s-transferase pl polymorphism to imatinib mesylate resistance in chronic myelogenous leukemia patients according to haematology response at General Hospital Haji Adam Malik and Branch Hospital in Kota Medan.

Association of GSTP1 gene (I105V) polymorphism with acute leukaemia. Journal of genetics.2012;1-4.

6. Jameson J.L. et al. Harrison's Principles of Internal Medicine Ed. 20th . United States: Mc-Graw Hill. 2018;748-757

7. Rossari F, Minutolo F, Orciuolo E. Past, present, and future of Bcr-Abl inhibitors: from chemical development to clinical efficacy. Journal of hematology \& oncology. 2018;11: 1-2,5.

8. Sailaja K, Surekha D, Rao D.N, Rao D.R., Vishnupriya S. Association of the GTSP1 gene (Ile105Vall) polymorphism with chronic myeloid leukemia. Asian pacific journal of cancer prevention. 2010; 11:461464

9. Haznedaroglu, IC. Monitoring the Response to Tyrosine Kinase Inhibitor (TKI) Treatment in Chronic Myeloid Leukemia (CML) . Mediterr J Hematol Infect Dis 2014,;6(1)

10. Rostami G., et al. Influence of gluthathione S-transferase (GSTM1, GSTT1, and GSTP1) genetic polymorphism and smoking on susceptibility risk of chronic myeloid leukemia and treatment response. Molecular genetics and genomic medicine. 2019; 7(717):1-10

11. Idris, H.M., Elderdery A.Y., Khalil, H.B., Mills J. Genetic polymorphism of GSTP1, GSTM1, and GSTT1 genes and susceptibility to chronic myeloid leukemia. Asian pacific journal of cancer prevention. 2020; 20:253-257
12. Banescu, C, Trifa, A.P, Voidazan, S, Moldovan, V.G, Macarie, I, Lazar, E.B, Dima, D, Duicu, C, Dobreanu,M. CAT, GPX1, GSTM1, GSTT1, and GSTP1 genetic polymorphisms in chronic Myeloid Leukemia : case-control study. Research Article.2014; 6

13. Karkucak, M., Yakut, T., Gulter T., Ali R. Investigation of GSTP1 (Ile105Val) gene polymorphism in chronic myeloid leukemia patients. International journal of human genetics.2012;12(3): 145-149

14. Elhoseiny, S., El-Wakil, M., Fawzy, M. and Rahman, A.A. GSTP1 (Ile105Val) gene polymorphism: risk and treatment response in chronic myeloid leukemia. Journal of Cancer Therapy.2013; 5(01):1.

15. Hoffman R, Benz EJ, Silberstein LE, Heslop HE, Weitz JI, Anastasi J, Salama ME, Abutalib SA. 2018. Hematology: Basic Principles and Practice. 7th ed. Philadelphia: Elsevier. 2018; 861-1061

How to cite this article: Lubis $A B$, Gatot D, Handayani $S$ et.al. The association of glutathione s-transferase $\mathrm{p} 1$ polymorphism to imatinib mesylate resistance in chronic myelogenous leukemia patients according to haematology response at General Hospital Haji Adam Malik and Branch Hospital in Kota Medan. International Journal of Research and Review. 2021; 8(9): 551-557. DOI: https://doi. org/10.52403/ijrr.20210970 